 \\ Раздел 1 \\ ПЕДАГОГИЧЕСКАЯ ПСИХОЛОГИЯ И ПСИХОЛОГИЯ РАЗВИТИЯ
}

\section{ДЕТИ ШЕСТИ-СЕМИЛЕТНЕГО ВОЗРАСТА И \\ ЭЛЕКТРОННЫЕ ГАДЖЕТЫ}

Борцова М. В., Некрасов С.Д.

Согласно исследованиям психологов (Л.И. Божович, Л.С. Выгодский, В.В. Давыдов, К.Н. Поливанова, Д.Б. Эльконин и др.) возраст 6-7 лет является одним из нормативных критических периодов развития ребенка, в котором ведущей деятельностью является игра. В этом возрасте происходит подготовка к будущей учебной деятельности, и как следствие, многие дети традиционно посещают подготовительные занятия в школе.

К возрасту 6-7 лет у многих детей, проживающих в городе с родителями, сформирован традиционный порядок жизни. В будни день начинается с дошкольного образовательного учреждения, после 18.00 заканчивается дома. В выходной или праздник ребенок весь день проводит в семье (с мамой, с папой, с братьями или сёстрами, с бабушкой и дедушкой и др.). В нынешнее время традиционный порядок жизни детей дополнен компьютером, планшетом, смартфоном и другими электронными гаджетами, часто более доступными детям, чем взрослым членам семьи.

Использование детьми электронных гаджетов, с одной стороны, позволяет ребенку играть в виртуальные игры, смотреть мультики, обретать способности пользователя компьютера, общаться с виртуальным собеседником. С другой стороны, уменьшает время общения ребенка с другими членами семьи, нахождения вне дома, игры со сверстниками, взаимодействия с реальным миром. Можно полагать, что использование 6-7-летними детьми электронных гаджетов внесло в традиционный порядок бытия детей как нерегулируемые, так и регулируемые изменения.

На развитие каких возрастных новообразований оказывает существенное влияние использование 6-7-летними детьми электронных гаджетов? Усвоению каких возрастных норм общения способствует виртуальное общение? На развитие каких свойств личности оказывает реальное воздействие использования детьми электронных гаджетов? Способности решения каких задач бытия обретаются детьми в компьютерных играх? Каким должен быть оптимальный уровень регулирования родителями использования детьми электронных гаджетов?

Как показывают наши исследования, существуют различные уровни регулирования родителями использования детьми электронных гаджетов. 
Можно выделить две крайние группы родителей, различающихся взглядами на использование детьми электронных гаджетов: родителей с низким и родителей с высоким уровнем нормирования использования ребенком электронных гаджетов.

Родители с низким уровнем нормирования использования ребенком электронных гаджетов считают, чем раньше ребенок научится самостоятельно использовать тот или иной электронный гаджет, тем быстрее он обретет способности решать задачи бытия, применяя возможности технических устройств. Считают, что ребенок сам научится организовывать свое свободное время, не привлекая для этого время родителей. Родители этой группы предпочитают почти не вмешиваться в этот процесс, мало регулировать время и содержание использования ребенком планшета, смартфона, компьютера и других электронных гаджетов.

Родители с высоким уровнем нормирования использования ребенком электронных гаджетов считают, что следует нормировать время использования ребенком электронных гаджетов, стараться находить время для обучения элементарным функциям планшета, сопровождать решение ребенком задач бытия с использованием гаджета, регулировать время самостоятельного общения ребенка с техническими устройствами. Считают, что необходимо обучать ребенка организовывать свое свободное время. Родители этой группы предпочитают регулировать время и содержание использования ребенком планшета, смартфона, компьютера и других электронных гаджетов.

Можно предположить, что существуют отличия в развитии детей 6-7летнего возраста (усвоение возрастных норм общения, развития свойств личности, обретение способностей решать задачи), родители которых различаются уровнем нормирования использования ребенком электронных гаджетов.

В возрастной психологии усвоение норм общения детьми 6-7-летнего возраста со сверстниками и взрослыми рассматривается как проявляющиеся попытки оценки ребенком своего поведения, попытки действовать в соответствии с теми моральными нормами, которые усваиваются в обсуждении со взрослыми, в общении со сверстниками, в выражении своих чувств, в сопереживании и сочувствии [1]. Выделим следующие возрастные нормы общения, которые полагаем, являются важными для многих детей 6-7-летнего возраста: нормы «приветствия», «благодарности», «просьбы», «готовности помогать».

Согласно Л.С. Выготскому в процессе воспитания «в непосредственном общении и совместной деятельности с взрослыми у ребенка формируются интегрированные свойства личности - нравственные качества, которые, закрепляясь в нравственном опыте ребенка, обусловливают его нравственные действия, поступки и отношения» [2] (добрый, вежливый, справедливый, скромный, заботливый, честный, бережливый и др.). Выделим следующие свойства личности, которые полагаем, получают развитие для многих детей 67-летнего возраста: «бережливость», «щедрость», «честность», «физическая активность», «драчливость», «агрессивность». 
Выделим также некоторые способности решать задачи, которые может обрести ребенок 6-7-летнего возраста, с помощью электронных гаджетов: «способности принимать решения в компьютерных играх», «способности концентрации внимания на игровых задачах», «способности слушать указания родителей в использовании планшета», «способности задумываться о последствиях своих действий в компьютерных играх», «способности ребенка общения с новыми детьми», «способность ребенка использовать планшет», «способность оценивать свои умения использовать компьютер» и др.

Инструментами исследования были методики наблюдения за поведением детей и экспертные оценки их родителей, которые, на наш взгляд, являются наиболее валидными и позволяют получить достоверные факты об отличиях в развитии детей 6-7-летнего возраста, различающихся использованием электронных гаджетов. Причем при проведении наблюдения за детьми 6-7летнего возраста необходимо для повышения валидности соблюдать основные требования: не влиять на ситуацию наблюдения, непредвзято регистрировать единицы наблюдения, одинаково соблюдать условия наблюдения и др. [4]. Данные положения были учтены при разработке методик наблюдения, опроса, экспертных оценок: опросник «Сведения о родителях»; наблюдение «Соблюдение ребенком норм общения» и «Ребенок и компьютер»; экспертные оценки «Свойства личности ребенка» и «Способности ребенка».

Для поиска эмпирических подтверждений гипотезы было проведено пятимесячное лонгитюдное исследование, в котором участвовали четыре ребенка 6-7-летнего возраста и их родители. Родители одних детей постоянно нормировали использование детьми электронных гаджетов, родители других детей - непостоянно. Методики проводились раз в месяц, в том числе в апреле, мае, июне, июле, августе. Кроме того, в одной семье велось еженедельное наблюдение за поведением ребенка с обязательной фиксацией данных в дневнике наблюдения.

Математическими методами анализа были: протоколирование собранных с помощью методик данных в EXCEL, вычисление средних значений «Соблюдения ребенком норм общения», «Свойства личности ребенка», «Способности ребенка», построение диаграмм ежемесячных изменений значений параметров норм общения у детей, различающихся уровнем нормирования родителями использования ими электронных гаджетов [3].

Сформулируем основные выводы.

Во-первых, у детей в 6-7-летнем возрасте, различающихся уровнем нормирования родителями использования ими электронных гаджетов можно отметить отличия в развитии, в том числе отдельных норм общения, некоторых свойств личности и способностей решать задачи бытия.

Во-вторых, дети в семьях с высоким уровнем нормирования использования ребенком электронных гаджетов одинаково в течение исследования (около полугода) проявляли нормы вежливости («приветствия», «благодарности», «просьбы», «готовности помогать»), как со своими родителями, так и с чужими людьми на улице. У них отмечены стабильно высокие показатели таких свойств 
развития личности, как «бережливости», «щедрости», «честности», «физической активности».

У детей в семьях с высоким уровнем нормирования использования ребенком электронных гаджетов отмечены стабильно высокие показатели отдельных способностей, в том числе «способности концентрации внимания на игровых задачах», «способности ребенка общения с новыми детьми», «способности принимать решения в компьютерных играх», «способности слушать указания родителей в использовании планшета», «способности задумываться о последствиях своих действий в компьютерных играх». Вместе с тем у них слабо развиты такие способности, как «способность ребенка использовать планшет», «способность оценивать свои умения использовать компьютер».

В-третьих, дети в семьях с низким уровнем нормирования использования ребенком электронных гаджетов по-разному в течение исследования (около полугода) проявляли нормы вежливости («приветствия», «благодарности», «просьбы», «бережливости», «готовности помогать») как со своими родителями, так и с чужими людьми на улице. Помимо этого, при введении постоянного нормирования использования электронных гаджетов у детей резко возрастали такие нормы общения, как «просьбы» и «готовности помогать» не только своим родителям, но и чужим людям на улице.

У них отмечены нестабильно изменяющиеся уровни развития отдельных свойств личности, в том числе «бережливости», «щедрости», «честности», «физической активности». При этом введение постоянного нормирования использования электронных гаджетов у детей способствовало возрастанию показателей развития свойств «бережливости», «щедрости», «честности», и одновременно снижению показателей «драчливости» и «агрессивности».

Дети в семьях с низким уровнем нормирования использования ребенком электронных гаджетов, нестабильно и по-разному проявляли обретение способностей: «способности принимать решения в компьютерных играх», «способности концентрации внимания на игровых задачах», «способности слушать указания родителей в использовании планшета», «способности задумываться о последствиях своих действий в компьютерных играх», «способности ребенка общения с новыми детьми», «способности ребенка использовать планшет», «способности оценивать свои умения использовать компьютер» и др.

Так, до нормирования они демонстрировали одинаково высокие показатели таких способностей, как «способность ребенка использовать планшет», «способность оценивать свои умения использовать компьютер», «способность слушать указания родителей в использовании планшета», однако после нормирования показатели этих способностей снизились.

Отметим, что поиски оптимального уровня регулирования родителями использования детьми электронных гаджетов, исследования особенностей развития детей 6-7-летнего возраста, различающихся уровнем нормирования использования электронных гаджетов, еще далеки до завершения. Вместе с тем считаем, что результаты исследования могут быть полезны родителям и 
педагогам для выработки правил и норм использования электронных гаджетов детьми 6-7-летнего возраста.

\section{Литература}

1. Божович Л.И. Проблемы формирования личности /под ред. Д.И.Фельдштейна. М.: Институт практической психологии. 1995.

2. Выготский Л. С. О двух направлениях в понимании природы эмоций в зарубежной психологии вначале ХХ в. // Вопросы психологии. 1968. № 2.

3. Некрасов С.Д. Математические методы в психологии (MS Excel). Краснодар: Кубанский гос. ун-т, 2014. URL: http://docspace.kubsu.ru/docspace/handle/1/295.

4. Некрасов С.Д. Как составить психологический портрет человека. Краснодар: Кубанский гос. ун-т, 2016.

\section{ВЛИЯНИЕ ДЕТСКО-РОДИТЕЛЬСКИХ ОТНОШЕНИЙ НА МЕЖЛИЧНОСТНОЕ ВЗАИМОДЕЙСТВИЕ СТАРШИХ ДОШКОЛЬНИКОВ СО СВЕРСТНИКАМИ}

Бочкарева C.H.

Развитие ребенка в каждой семье зависит от характера сложившейся в ней отношений, от стиля и типа воспитания и личности самих родителей. Можно с уверенностью сказать, что эти отношения определяют будущее человека: его отношения с окружающими, особенности поведения и характера. В современное время родители стали чаще обращаться к психологу за помощью в плане воспитания детей. Создаются центры, в которых родители учатся взаимодействовать со своими детьми. Поэтому тема зарождения и становления межличностных отношений между родителями и между сверстниками чрезвычайно актуальна, так как множество негативных и деструктивных явлений среди молодежи, наблюдаемых в последнее время (жестокость, отчужденность, агрессия) имеют свои истоки в раннем и дошкольном детстве, основанные на детско-родительских отношениях и отношениях со сверстниками.

Так в психологическом словаре термин «общение» рассматривается как процесс установления и развития контактов между людьми, порождаемый их потребностями в совместной деятельности. Общение объективно порождается совместной жизнедеятельностью людей в системах их внешних отношений с социальной средой и внутри групповых межличностных отношении.

По выражению В.А. Петровского, “в процессе осуществления деятельности человек объективно вступает в определенную систему взаимосвязей с другими людьми". Таким образом, содержанием любого взаимодействия является связь, обмен (действиями, предметами, информацией и т.д.) и взаимное влияние.

Семейное общение является существенной частью функционирования общества как такового. Однажды у Конфуция поинтересовались, почему мудрец не участвует в государственных делах и на это китайский философ ответил следующим образом: "В повседневности проявляю разумное 